\title{
INTERNATIONAL PARENTAL CHILD ABDUCTION IN THE MALAYSIAN LEGAL CONTEXT: ADDRESSING ISSUES AND THE WAY FORWARD*
}

\author{
Abdul Ghafur Hamid** \\ Zaleha Kamaruddin***
}

\begin{abstract}
The number of international parental child abduction cases is gradually increasing and the problem has now become a global phenomenon. The worrying situation is that the problem in question is extremely difficult to resolve due to conflicting substantive and procedural laws in various countries. The 1980 Child Abduction Convention is an attempt to address the problem by means of an automatic return mechanism of the abducted child to his country of habitual residence. However, a Malaysian parent would not have that privilege as Malaysia is not a party to the Convention. The primary focus of the present work is to examine whether Malaysia has adequate legal and procedural framework to address the issue of crossborder parental child abduction. The present work makes a thorough analysis of the dual legal system of Malaysia, namely both the civil law and Islamic law streams when dealing with child custody and parental child abduction and assesses in-coming and out-going international parental child abduction cases decided by the Malaysian courts. The article finds that although in the long run, Malaysia should accede to the Child Abduction Convention, there are legitimate concerns on the part of stakeholders and on the fact that the opinion on the ground is against the accession. The article concludes that in the meantime, section 52 of the
\end{abstract}

\footnotetext{
* Work on this article is funded under the Fundamental Research Grant Scheme (FRGS) (Project ID: FRGS16-001-0500) granted by the Ministry of Education, the Government of Malaysia.

** Professor, Department of Civil Law, Ahmad Ibrahim Kuliyyah of Laws, International Islamic University of Malaysia. Email: ghafur@iium.edu.my.

*** Professor, Department of Islamic Law, Ahmad Ibrahim Kuliyyah of Laws, International Islamic University of Malaysia. Email: drzaleha@iium.edu.my.
} 
Child Act 2001 should be amended to strengthen the legal regime regulating parental child abduction in Malaysia.

Keywords: parental child abduction, conflict of laws, cross-border abduction, the Malaysian legal context, Hague Abduction Convention

\title{
PENCULIKAN KANAK-KANAK LINTAS SEMPADAN OLEH IBUBAPA DALAM KONTEKS PERUNDANGAN MALAYSIA: MENANGANI ISU-ISU DAN HALA TUJU
}

\begin{abstract}
ABSTRAK
Bilangan kes penculikan kanak-kanak antarabangsa oleh ibu bapa semakin meningkat dan kini menjadi fenomena global. Keadaan ini kian menjadi barah dan amat sukar diselesaikan kerana undang-undang substantif dan prosedur yang bercanggah di pelbagai negara. Konvensyen Penculikan Kanak-Kanak 1980 adalah suatu usaha untuk mengatasi masalah ini dengan cara mengembalikan kanak-kanak yang diculik ke kediamannya yang biasa. Walau bagaimanapun, ibubapa di Malaysia tidak mempunyai keistimewaan itu kerana Malaysia masih belum menandatangani Konvensyen tersebut. Fokus utama pada ketika ini adalah untuk mengkaji sama ada Malaysia mempunyai kerangka undang-undang dan prosedur yang mencukupi untuk menangani isu penculikan kanak-kanak merentas sempadan. Makalah ini menganalisa sistem dwi-perundangan di Malaysia, iaitu undang-undang sivil dan aliran undang-undang Islam berkenaan dengan jagaan kanak-kanak dan penculikan kanak-kanak ibu bapa, dan menilai kes-kes penculikan kanak-kanak antarabangsa semasa dan yang telah selesai didengari oleh Mahkamah-Mahkamah Malaysia. Makalah ini mendapati walaupun dalam jangka masa panjang, Malaysia sepatutnya menyertai Konvensyen Penculikan Kanak-kanak, namun terdapat kebimbangan yang sah oleh pihak-pihak berkepentingan yang menjustifikasi ketidak-sertaan. Makalah ini menyimpulkan bahawa seksyen 52 Akta Kanak-Kanak 2001 perlu dipinda untuk memperkuatkan rejim undang-undang yang mengawalselia penculikan kanak-kanak oleh ibu bapa di Malaysia.
\end{abstract}

Kata Kunci: penculikan kanak-kanak oleh ibubapa, konflik perundangan, penculikan merentas sempadan, konteks perundangan Malaysia, The Hague Abduction Convention 


\section{INTRODUCTION}

Children are among the most vulnerable human beings who are in constant need of protection, especially in cases where parents are separated or have initiated divorce proceedings. A typical scenario of parental child abduction is when one parent removes or retains the child from the other, for the purpose of "seeking to gain an advantage in the expected or pending child-custody proceedings or whenever a parent fears losing the child in the expected or pending child-custody proceedings." Parental child abductions may take place either within the same country, or internationally.

In recent years, there has been a dramatic increase in cases of international abduction of children, which makes it a global phenomenon. There can be two versions of cross-border or international child abduction; removal and retention. The former occurs when a parent leaves the country with the child in contravention of a custody or visitation order obtained by the other parent. Meanwhile, the latter may occur when a parent takes a child overseas on an alleged vacation or visitation to grandparents and later does not return.

Compared to domestic parental child abduction cases, the number of cases of international child abduction is relatively small. However, they are often the most difficult to resolve due to conflicting jurisdictional issues. It is in the light of this jurisdictional issue and the need to develop adequate international child protection mechanism that various countries thought it necessary to come together to further discuss this grave issue. In 1976, Canada proposed the development of an international convention to lessen cases of cross border child abduction to The Hague Conference on Private International Law $(\mathrm{HCCH})$. The outcome of this proposal was the 1980 Hague Convention on the Civil Aspects of International Child Abduction. ${ }^{2}$

${ }^{1}$ See Beaumont \& McEleavy, The Hague Convention on International Child Abduction, (Oxford: Oxford University Press, 1999) 1.

2 The Hague Convention on the Civil Aspects of International Child Abduction, adopted at the Hague on October 25, 1980 and entered into force on December 1,1983 , herein after referred to as the "Hague Abduction Convention." For the text see https://www.hcch.net/en/instruments/conventions/full-text/?cid=24. See 
The Hague Abduction Convention is a multilateral treaty, ${ }^{3}$ which creates an automatic return mechanism of the abducted children to their country of habitual residence. The requirement of automatic return is designed with the view that the courts of the child's habitual residence are best suited to determine the issue of custodial rights and assess the best interests of the child. However, the provisions of The Hague Abduction Convention are applicable only among contracting States. Thus, in case where the child is abducted to a non-contracting State, it requires a parent to initiate new custody proceedings in that country in order to get the child back. Malaysia is not yet a party to the Convention, as such, if a Malaysian child is abducted to a foreign country by one of his parents, the left behind Malaysian parent has no recourse at all under the Convention but to follow a tedious and very expensive option of taking legal action against the abducting parent in a foreign jurisdiction.

This article does not address the issue of local child abduction but only focuses on the issue of cross-border or international child abduction. Since the emphasis is on international parental child abduction, which involves a foreign element, it will also need to touch briefly on the issues of conflict of laws. Hence, the following are the four main objectives of this paper:

(i) To measure how serious the problem is;

(ii) To emphasise the important role of private international law in dealing with this issue;

also A. E. Anton, "The Hague Convention on International Child Abduction," (1981) 30 Int'l \& Comp LQ 537, at 539-540; Dana R. Rivers, "The Hague International Child Abduction Convention and the International Child Abduction Remedies Act: Closing Doors to the Parent Abductor," (1989) 2 Transnat'l Law 589, at 616. See also, Elisa Perez-Vera, Explanatory Report on the 1980 Hague Child Abduction Convention, Hague Conference on Private International Law (HCCH), 1982, at 426, available at https://assets.hcch.net/upload/expl28.pdf, accessed 26 October 2017 (hereinafter Perez-Vera Report).

${ }^{3}$ To date, 97 countries are parties to the Hague Abduction Convention. See the latest status of the Convention on the $\mathrm{HCCH}$ website, accessed 8 June 2017: https://assets.hcch.net/docs/62b28229-4cec-4a93-a7d0-241b9ef3507e.pdf. 
(iii) To assess Malaysian substantive and procedural laws pertaining to in-coming and out-going parental child abduction cases; and

(iv) To consider ways and means to effectively suppress the issue of international parental child abduction in Malaysia.

The discussion now proceeds to the seriousness of the problem.

\section{HOW SERIOUS IS THE PROBLEM?}

Material gain is usually not the aim of a parental child abduction. The primary purpose of the abducting parent would be to exercise monopolistic care and control over the child in a new jurisdiction, which is favourable to him or her. In most cases, the forced relocation will have a detrimental effect on the child. The child has to face social, educational and linguistic difficulties in adjusting to life in the new place of residence and at the same time to have psychological feeling of detachment from his or her home environment. On the other hand, the distress and feeling of losing a loved one suffered by the left-behind parent would also be taken into consideration. Conflict over the care and control of a child following the breakdown of a marriage or divorce is undoubtedly an emotional issue. This is only exacerbated when an international element is added. ${ }^{4}$

According to the available statistics, the number of international parental child abduction cases is high and it is gradually increasing. In the USA, for example, in 2015 alone, more than 600 children, were reportedly abducted by a parent from the United States to another country. ${ }^{5}$ A study was conducted in the European Union in 2015 and it was found that the two main root causes for parental child abductions are, (i) international marriages (that is, a marriage between persons from different jurisdictions), and (ii) divorce cases. In the EU Member countries, international marriages as a percentage of all marriages are from $23 \%$ to as high as $32 \%$ and divorces of couples in international

\footnotetext{
${ }^{4}$ Beaumont \& McEleavy, 1-2.

${ }^{5}$ Annual Report on International Parental Child Abduction (IPCA) (2016) US Department of State, Bureau of Consular Affairs, 5.
} 
marriages as a percentage of all divorces in EU countries are from $13 \%$ to as high as $48 \%{ }^{6}$

It is therefore evident that the issue of international parental child abduction is a global phenomenon and Malaysia is not an exception. Keeping up with the accelerating pace of globalisation, the number of Malaysians working, doing business or studying in foreign countries may contribute to the rise in these numbers. On the other hand, quite a number of foreign nationals have also chosen to work, do business or study in Malaysia. Hence, there is an increase in cross-cultural or international marriages and as a Muslim may only marry another Muslim, there are also situations where many non-Muslims convert in order to marry a Muslim. Unfortunately, some of these marriages end up in divorces. When this happens, if the couples have children, many cases have seen, the custody of the children being contested by the couples. In view of the nature of the marriages, once divorced some individuals no longer wish to reside in Malaysia. This then results in a situation where the individual not only leaves Malaysia, but also takes their child or children with them. Worst still are cases, which involves couples who convert out of Islam to return to their original religion. This often results in highly-publicised local parental abduction cases ${ }^{7}$ and there are also a few remarkable crossborder parental child abduction cases decided by the Malaysian courts, ${ }^{8}$ which will be discussed in the later section. These cases may be the tip of the iceberg and many cases would go unreported. Nonetheless, the

${ }^{6}$ Cross-Border Parental Child Abduction in the European Union, Study for the LIBE Committee of the European Parliament, (2015) 39, 42.

${ }^{7}$ Shamala a/p Sathiyaseelan v Dr Jeyaganesh a/l C Mogarajah [2004] 2 MLJ 241; Indira Gandhi a/p Mutho v Pengarah Jabatan Agama Islam Perak \& Ors [2013] 5 MLJ 552; Indira Gandhi a/p Mutho v Patmanathan a/l Krishnan (anyone Having and Control Over Prasana Diksa) - [2014] MLJU 547; Indira Gandhi a/p Mutho v Ketua Polis Negara - [2014] MLJU 1287; Indira Gandhi a/p Mutho v Patmanathan a/l Krishnan (anyone having and control over Prasana Diksa) - [2015] 7 MLJ 153.

${ }^{8}$ Mahabir Prasad v. Mahabir Prasad [1982] 1 MLJ 189; In the marriage of Y\&K Raja Bahrin (1986) 11 The Family Law Report 233; Herbert Thomas Small v Elizabeth Mary Small (2006) 6 MLJ 372; Nicholas Tan Chye Seng v Au Gek Wee, High Court (Kuala Lumpur) Case No. 24-149-07-2013. 
problem is a real and serious one. As such, there is a need to deliberate on the solutions that can best settle this grave and menacing problem.

\section{THE ROLE OF PRIVATE INTERNATIONAL LAW}

Since international parental child abduction cases encompass issues of conflict of laws or private international law, it would be necessary to touch briefly on what conflict of laws is and what types of conflict of laws issues may arise from parental abduction.

There are two reasons why a conflict of laws may arise:

(1) the laws of different countries are different; and

(2) people from different countries meet and do transactions with their respective counterparts.

As mentioned above, in today's modern world, people no longer reside in one country only. Many people travel overseas for a variety of purposes. They are involved in private, personal or commercial transactions with foreign counterparts. Disputes may arise from these transactions, which involve a 'foreign element'. The foreign element is 'an element which is connected with a foreign system of law.' In its narrower interpretation, the foreign system of law means the law of a foreign country. However, according to Cheshire, "in its wider sense of the term, the foreign system of law means a distinctive legal system prevailing in a territory other than that in which the court functions." "It, therefore, includes, not merely the law existing in a State under a foreign political sovereignty, but also the law prevailing in a sub-division of the political State of which the forum is part. Thus, as far as English courts are concerned, the law of Scotland is just as much a foreign law as the law of Japan or Brazil."

In this sense, in a federal State like Malaysia, there can be a conflict of laws issue within the country itself. There can be conflict of laws

9 J.J Fawcett \& J.M. Carruthers, Cheshire, North \& Fawcett Private International Law, $14^{\text {th }}$ ed. (Oxford: Oxford University Press, 2008) 9.

${ }^{10}$ Ibid. See also Jonathan Hill \& Maire Ni Shuilleabhain, Clarkson \& Hill's Conflict of Laws, ${ }^{\text {th }}$. ed. (Oxford: Oxford University Press, 2016), 1. 
between the laws of various states in Malaysia. ${ }^{11}$ There can be conflict of laws between Muslims and non-Muslims as their personal laws are different. There can also be conflict of jurisdiction between Shari'ah courts and civil courts and conflict of jurisdiction is one of the domains of conflict of laws.

A foreign element may be involved, for example, if one of the parties is a foreign national, if a contract is made in a foreign country, if a tort is committed in a foreign country, if a marriage is contracted in a foreign country, if the child custodial order of a court is obtained in a foreign country, and so on. ${ }^{12}$

Since the later part of the nineteenth century, courts in many countries have begun to consider that in a situation where a foreign element is involved, it is not fair or just for a local court to decide according to the local law (lex fori or law of the forum) only. It is the beginning of the fascinating subject of conflict of laws. Most of the countries of the world has acknowledged and accepted the fundamental principle of law that to avoid injustice and to be able to give redress to the injured party, the local court has to take into consideration the relevant foreign law in a case that involves a foreign element. ${ }^{13}$ The local court has to select the applicable law (governing law) for the case before it. To put it another way, the local court has to make a 'choice of law', that is, it has to make a choice between the local law and the relevant foreign law; to determine which law is the governing law or the applicable law. This choice of law is to be done by referring to the "rules of conflict of laws" and these rules have come to be known as "private international law'. As distinct from public international law, private international law (or rules governing conflict of laws) is part of the domestic law of a state. ${ }^{14}$ Malaysia as a State has its own rules of conflict

${ }^{11}$ R.H. Hickling \& Wu Min Aun, Conflict of Laws in Malaysia, (Kuala Lumpur: Butterworth Asia, 1995), 25-26.

${ }^{12}$ See Jonathan Hill, Clarkson \& Hill's Conflict of Laws, 1.

${ }^{13}$ Cheshire, North \& Fawcett Private International Law, 4-5.

${ }^{14}$ Abdul Ghafur Hamid @ Khin Maung Sein, Public International Law: A Practical Approach, $3^{\text {rd }}$. ed. (Petaling Jaya: Sweet \& Maxwell Asia, 2011) 3. 
of laws or private international law. This can be found in Malaysian statutes $^{15}$ and judicial decisions.

\section{The three functions of conflict of laws}

Private international law is concerned with one or more of the following three questions:

(1) Jurisdiction of the local court;

(2) The choice of law; and

(3) Recognition and enforcement of foreign judgments. ${ }^{16}$

Jurisdiction is always the first determination for a court of law to make. It has to decide whether it has jurisdiction to hear the case. It is more crucial when the case before it involves a foreign element. The court must have jurisdiction over the parties as well as the subject-matter. The bases of jurisdiction accepted in both common law and civil law countries include the following:

(i) presence of the defendant within the territorial jurisdiction of the court; and

(ii) submission. ${ }^{17}$

The choice of law (i.e. the choice between the local law and the relevant foreign law) is the most crucial question for the court to decide, by applying rules of conflict of laws. ${ }^{18}$ The recognition and enforcement of foreign judgments comes to play, for example, when a plaintiff has obtained a favourable judgment in a litigation abroad and needs to

\footnotetext{
15 "Statutes" includes the Law Reform (Marriage and Divorce) Act 1976, the Islamic Family Law Enactments, the Child Act 2001, the Penal Code, the Courts of Judicature Act 1964, the Rules of Court 2012, and the Reciprocal Enforcement of Judgments Act 1968, to name a few, but there is no specific statute that entirely deals with rules of conflict of laws.

${ }^{16}$ Cheshire, North \& Fawcett Private International Law, 7.

${ }^{17}$ Jonathan Hill, Clarkson \& Hill's Conflict of Laws, 104-107.

${ }^{18}$ Ibid., 9-19.
} 
enforce it locally. It is important to ascertain whether the local law will recognise or permit the enforcement of the foreign judgment. ${ }^{19}$

\section{How to avoid conflict of laws}

There are two possible ways to avoid conflict of laws or to diminish the inconvenience that results from conflicting national laws:

(1) Unification of domestic laws; and

(2) Unification of private international law. ${ }^{20}$

The first is to unify, by means of international conventions, the domestic laws of the various countries on important legal topics. A good example is the adoption by the UNCITRAL of The United Nations Convention on Contracts for International Sale of Goods (CISG), $1980^{21}$ for the unification of sale of goods laws of various countries.

The second is to secure the unification of the rules of private international law in order that the decision on a case involving a foreign element will be the same irrespective of the country of its trial. The Hague Conference on Private International Law $(\mathrm{HCCH})$ has been responsible for the unification of private international law in a number of legal topics ${ }^{22}$ and the 1980 Hague Abduction Convention is one example of the results of these efforts.

It is noteworthy that these private international law conventions are not unification of internal laws (in the current case the unification of child custody laws) of various countries. By acceding to these

${ }^{19}$ Cheshire, North \& Fawcett Private International Law, 8.

${ }^{20}$ Ibid., 10-11.

${ }^{21}$ United Nations Convention on Contracts for International Sale of Goods (CISG), adopted by the UNCITRAL in Vienna on 11 April 1980, entered into force on 1, January 1988; 1489 UNTS 3, (89 States parties).

22 The Hague Conference on Private International Law ( $\mathrm{HCCH})$ is an intergovernmental organization in the area of private international law that develops and administers several international conventions, protocols and soft law instruments, accessed 12 November 2018, https://www.hcch.net/en/home. 
conventions, it would not be necessary to substantially amend or revise our domestic laws, in particular, Islamic law enactments. These conventions are merely unification of private international law in the field of family matters.

The three primary personal connecting factors applied in the contemporary world are related to; (i) domicile (ii) nationality and (iii) habitual residence. Whereas domicile is the main personal connecting factor used in common law countries and nationality is the practice of the civil law countries, both common law and civil law jurisdictions are now increasingly using habitual residence as a preferred connecting factor in many areas. ${ }^{23}$ The main obligation of states parties to the 1980 Hague Abduction Convention is to promptly return the in-coming abducted child to his country of habitual residence $e^{24}$ and if the abduction is outgoing, to inform the Central Authority of the other State party to promptly return the child from their country. ${ }^{25}$

The following discussions will touch upon the existing Malaysian statutes and judicial decisions in addressing cases of both in-coming and out-going cases of international parental child abduction.

\section{ASSESSING MALAYSIAN LAWS PERTINENT TO PARENTAL CHILD ABDUCTION}

There are the two main statutes governing the custody of children in Malaysia; the Islamic Family Law (Federal Territories) Act 1984 (IFLA) and the Islamic Family Law Enactments of various States, which are applicable to Muslims, and the Law Reform (Marriage and Divorce) Act 1976 (LRA) as well as the Guardianship of Infants Act 1961 (Revised 1988) (Act 351), which are meant for non-Muslims. The Penal Code and the Child Act 2001 need also be assessed to see whether they can contribute to combatting of international parental child abduction.

\footnotetext{
${ }^{23}$ See Cheshire, North \& Fawcett Private International Law, 153-195.

${ }^{24}$ Article 1(a), the 1980 Hague Abduction Convention.

${ }^{25}$ Articles 9-10, ibid.
} 


\section{Islamic Family Law (Federal Territories) Act 1984 and Islamic Family Law Enactments}

As in other Muslim countries, Malaysia's statutory Islamic family law enactments normally follow the Shari'ah principles. According to Islamic Family Law (Federal Territories) Act 1984 (IFLA), for example, "the mother shall be of all persons the best entitled to the custody of her infant children. ${ }^{26}$ The qualifications for a mother to be entitled to the right of hadhanah are: "(a) she is a Muslim; (b) she is of sound mind; (c) she is of an age that qualifies her to bestow on the child the care, love, and affection that the child may need; (d) she is of good conduct from the standpoint of Islamic morality; and (e) she lives in a place where the child may not undergo any risk morally or physically., ${ }^{, 27}$ However, "a mother may lose her right of custody if, for example, she marries with a person not related to the child within the prohibited degrees (nonmahram) if her custody in such case will affect the welfare of the child, or she renounces Islam." 28

The right of custody of the mother as a general rule ends for a son when he attains the age of seven and for a daughter when she attains the age of nine. ${ }^{29}$ After termination of the right of the mother, "the custody devolves upon the father, and if the child has reached the age of discernment (mumaiyiz), he or she shall have the choice of living with either of the parents, unless the Court otherwise orders." ${ }^{30}$

When the Court makes an order for custody, "paramount consideration shall be the welfare of the child." ${ }^{31}$ It has also to give the parent deprived of custody the right of access to the child as it considers fit and to "prohibit the person given custody from taking the child out of

\footnotetext{
${ }^{26}$ Islamic Family Law (Federal Territories) Act 1984, section 81(1).

${ }^{27}$ Ibid., section 82.

${ }^{28}$ Ibid., section 83 (a) \& (d)

${ }^{29}$ Ibid., section 84(1).

${ }^{30}$ Ibid., section 84(2).

${ }^{31}$ Ibid., section 86(2).
} 
Malaysia." ${ }^{32}$ Although there is no direct criminalisation of parental child abduction, the provisions impliedly provides for a principle that the child has a right to have personal contact and access with both parents and in order to ensure that there is a continuous relationship between the child and his/her parents, the custodial parent is prohibited from bringing the child out of Malaysia with the intention to separate the child from the left-behind parent. This provision partially protects cross-border parental child abduction as it prohibits the custodial parent from bringing the child outside of Malaysia. Alas, the law does not impose a similar prohibition on the non-custodial parent.

Nevertheless, the law does empower the court, on application of the child's father or mother, to issue an injunction restraining the other parent from taking the child out of Malaysia. ${ }^{33}$ Failure to comply with such a court order is punishable as a contempt of court. ${ }^{34}$ This provision also serves as a deterrent to parental child abduction since the failure to comply with the order of court shall be punishable as a contempt of court. The Islamic Family Law Enactments of various States also have very similar provisions on custody of children. ${ }^{35}$

The above provisions of the Malaysian law that prohibit the custodial parent from taking the child out of Malaysia and also empowers the court to issue an injunction to restrain a parent from taking the child out of Malaysia could to some extent contribute towards suppressing international parental child abductions. However, the Malaysian courts appear to be quite reluctant to allow such an injunction unless the applicant could prove this possibility with a strong evidence. In Sokdave Singh a/l Ajit Singh $v$ Sukvender Kaur a/p Daljit Singh, the father argued that the mother might take the child out of Malaysia if she landed an overseas job. The father's application for injunction was nevertheless

\footnotetext{
${ }^{32}$ Ibid., section 87(2)(d) and (e).

${ }^{33}$ Ibid., section 105(1).

${ }^{34}$ Ibid., section 105(3).

${ }^{35}$ See, for example, Islamic Family Law (State of Selangor) Enactment 2003, Enactment No 2 of 2003, sections 82-87 and 105.
} 
rejected by the court on the ground that it was very unlikely for the child to be abducted abroad. ${ }^{36}$

There still is a possibility that a parent can plot to take the child out of the country in the pretext of visiting relatives or taking them for a holiday overseas and choose not to return. This is the common modus operandi in many international parental child abduction cases. If that happens, what would be the legal remedy for the left-behind parent? Unless and until the abducting parent and the child voluntarily returns to the original country, the left-behind parent has no other redress apart from initiating a tedious and extremely expensive litigation in a foreign jurisdiction.

\section{Law Reform (Marriage and Divorce) Act 1976}

The most important difference between IFLA and the Law Reform (Marriage and Divorce) Act (LRA) $1976^{37}$ is the underlying principle of the Islamic law that "the mother shall be of all persons the best entitled to the custody of her infant children." According to the LRA, there is no such differentiation between father and mother as to the right of custody of an infant, ${ }^{38}$ except "a rebuttable presumption that it is for the good of a child below the age of seven years to be with his or her mother." 39

Apart from that, similar provisions as stated in the IFLA are to be found in the LRA as well, such as: "paramount consideration to be given to the welfare of the child," right of access to the child, ${ }^{41}$ and to "prohibit the person given custody

${ }^{36}$ Sokdave Singh a/l Ajit Singh v Sukvender Kaur a/p Daljit Singh, [2001] MLJU 113.

${ }^{37}$ Law Reform (Marriage and Divorce) Act 1976, Act 164, hereinafter referred to as LRA.

${ }^{38}$ See, LRA, Section 88 (1).

${ }^{39}$ Ibid., section 88(3).

${ }^{40}$ Ibid., section 88(2).

${ }^{41}$ Ibid., section 89(2)(d). 
from taking the child out of Malaysia." $"$ The LRA also empowers the court, on application of the child's father or mother, to issue an injunction restraining the other parent from taking the child out of Malaysia. ${ }^{43}$ Failure to comply with such a court order is punishable as a contempt of court. ${ }^{44}$ All these are possible due to the efforts of the Malaysian Government for the harmonisation of Islamic law and Shari'ah in the field of family law.

\section{Penal Code}

According to the Penal Code, ${ }^{45}$ the main criminal law statute in Malaysia, the term 'abduction' can be found in section 359. However, the term is used to connote a different meaning, which is not compatible to the meaning of abduction used in the Hague Abduction Convention (wrongful removal or retention in breach of custodial rights ${ }^{46}$ ). Under the Penal Code, there are two different kinds of kidnapping, namely, kidnapping from Malaysia (section 360) ${ }^{47}$ and kidnapping from lawful guardianship (section 361). Although the former (section 360) is rather a very general provision and has nothing specifically to do with parental child abduction, the latter (section 361) may have some similarities.

Section 361 - kidnaping from lawful guardianship - reads as follows:

"Whoever takes or entices any minor under fourteen years of age if a male, or under sixteen years of age if a female, or any person of unsound mind, out of the keeping of the lawful guardian of such minor or person

${ }^{42}$ Ibid., section 89(2)(e).

${ }^{43}$ Ibid., section 101(1).

${ }^{44}$ Ibid., section 101(3).

${ }^{45}$ Penal Code, Laws of Malaysia, Act 574.

${ }^{46}$ The 1980 Hague Abduction Convention, Article 8.

${ }^{47}$ Section 360 of the Penal Code provides: "Whoever conveys any person beyond the limits of Malaysia without the consent of that person, or of some person legally authorized to consent on behalf of that person, is said to kidnap that person from Malaysia." 
of unsound mind, without the consent of such guardian, is said to kidnap such minor or person from lawful guardianship.

Explanation - The words 'lawful guardian' in this section include any person lawfully entrusted with the care or custody of such minor or other person.

Exception - This section does not extend to the act of any person who in good faith believes himself to be the father of an illegitimate child or who in good faith believes himself to be entitled to the lawful custody of such child, unless such act is committed for an immoral or unlawful purpose."

By virtue of the term "lawful guardian," one may think that it refers only to a father, who is regarded as a lawful guardian under Islamic law as well as civil law. However, the 'Explanation' to section 361 makes it clear that the term includes "any person who is lawfully entrusted with the care or the custody of such a minor." A mother can also be regarded as a lawful guardian for the purpose of the section. ${ }^{48}$ This is reaffirmed in the case of Syed Abu Tahir a/l Mohamed Ismail v Public Prosecutor, ${ }^{49}$ where the accused took away a Muslim minor girl without the consent of her mother with whom she was staying. The defence argued that since the mother was not a lawful guardian there was no offence under section 361 of the Penal Code. Zakaria Yatim J, rejecting the defence's argument, held that:

"[I]n considering the expression 'lawful guardian' in Section 361 of the Penal Code, the court must give it a meaning which accords not only with Section 5 of the Guardianship of Infants Act, ${ }^{50}$ but also with the explanation to Section 361 of Act 574. The words 'lawfully entrusted', which appear in the explanation, must be construed liberally. It is not intended that the entrustment should be made in a formal manner. It can

${ }^{48}$ Suzana Muhamad Said and Shamsuddin Suhor, "International Parental Child Abduction in Malaysia: Foreign Custody Orders and Related Laws for Incoming Abductions." Pertanika J. Soc. Sci. \& Hum., 20 (S)(2012): 101-110, at 106.

${ }^{49}$ Syed Abu Tahir a/l Mohamed Ismail v Public Prosecutor, [1988] 3 MLJ 485.

${ }^{50}$ Section 5 of the Guardianship of Infants Act 1961 provides that "In relation to the custody or upbringing of an infant or the administration of any property belonging to or held in trust for an infant ..., a mother shall have the same rights and authority as the law allows to a father, and the rights and authority of mother and father shall be equal." 
be done orally and is not even necessary that there should be direct evidence available about the entrustment as such. From the course of conduct and from the other surrounding circumstances, it would be open to the court to infer lawful entrustment in favour of the person in whose custody the minor is living and who is taking her care in all reasonable ways."

However, a crucial question that can be raised is: can a parent be liable for kidnapping (abduction) under section 361? Can a father be guilty of kidnapping or abduction of his own child under this section? By virtue of the interpretation of the "Explanation" to section 361 by the Malaysian court in Syed Abu Tahir case, it is probable that a mother can be regarded as a "legal guardian" and consequently a father could be guilty of kidnapping (abduction) of his own child from the mother who has obtained a court order for lawful custody of the child. However, the "Exception" to section 361 again makes it rather doubtful for a father to be guilty of kidnapping of his own child from the mother. This is because the father, the abductor, is also a person having legal rights over the child. There is no judicial precedent that directly addresses the matter. It appears that unlike some other countries, parental child abduction is not specifically a crime under the Penal Code of Malaysia.

\section{Child Act 2001}

The Child Act ${ }^{51}$ is the governing statute relating to the care and protection of children in Malaysia. The relevant provision relating to parental child abduction is section 52, which reads as follows:

"Any parent or guardian who-

(a) does not have the lawful custody of a child; and

(b) takes or sends out a child, whether within or outside Malaysia, without the consent of the person who has the lawful custody of the child commits an offence and shall on conviction be liable to a fine not exceeding ten thousand ringgit or to imprisonment for a term not exceeding five years or to both., ${ }^{, 52}$

\footnotetext{
${ }^{51}$ The Child Act 2001, Laws of Malaysia, Act 611

${ }^{52}$ Ibid., Section 52(1).
} 
"A person has lawful custody of a child if he has been conferred custody of the child by virtue of any written law or by an order of court, including the Shari' ah Court." ${ }^{, 53}$ The non-custodial parent, nevertheless, can rely on some defences. ${ }^{54}$

Under section 53 of the Child Act, "If there is reason to believe that a child had been taken or sent away without the consent of the person who has lawful custody of the child, the Court may make a 'recovery order' on application being made by any person who has the lawful custody of the child. Any person who intentionally obstructs an authorized person from exercising the powers under the recovery order commits an offence and shall on conviction be liable to imprisonment for a term not exceeding three years and to whipping not exceeding six strokes."

Section 52 of the Child Act covers parental child abduction within Malaysia as well as cross-border abduction. It is a very progressive legal provision, which partially criminalises parental child abduction. Under this section, parental child abduction is an offence (a crime) punishable up to five years imprisonment. However, the implementation of it or the interpretation of this core provision of the Child Act by the Malaysian courts is not at all encouraging. ${ }^{56}$

Furthermore, another weakness of Article 52 of the Child Act is that it is incomplete as it deals only with one side of parental child abduction, that is, one committed by non-custodial parent, and not covering the other side, that is, one committed by the custodial parent himself or herself. It appears that we need to revise the Child Act to cover both or to enact a special law on parental child abduction. If we look at the practice of another common law country, under the Child Abduction Act of 1984 of the United Kingdom, "it is a criminal offence for anyone connected with a child (for example, father, mother, any guardian of the child, or

${ }^{53} \mathrm{Ibid}$., Section 52(2).

${ }^{54}$ Ibid., Section 52(3).

${ }^{55}$ Ibid., Section 53

${ }^{56}$ See for example, Azman Abdul Talib v Suhaila Ibrahim [2004] CLJ 397 , where it is stated that the court will be very strict and careful to commit a parent to prison. 
any person who has custody of the child) to take him out of the UK for more than 28 days without the consent of any other person who has parental responsibility for that child (for example, father, mother, any guardian of the child, or any person who has custody of the child) or a consenting order from the courts. ${ }^{57}$ If it is a conviction on indictment, the punishment will be imprisonment for a term not more than seven years." ${ }^{, 58}$

\section{EVALUATING THE MALAYSIAN PRACTICE RELATING TO IN-COMING AND OUT-GOING PARENTAL ABDUCTION CASES}

\section{In-Coming Cases}

The first scenario is the in-coming cross-border parental child abduction; it occurs when a parent abducted his or her own child from a foreign country and comes and stays in Malaysia. In such a situation what would be the legal questions that needs to be addressed?

The case of State Central Authority $v$ Ayob $^{59}$ is illustrative of the difficulty of a left-behind parent when a child is abducted into Malaysia. In this case, the girl was five-year old and had lived in the United States all of her life. At the time of separation of her parents, an agreement was reached whereby the mother obtained custody rights and the father was given visitation rights. On 10 July 1995 the mother took the child to Malaysia without the permission of the father and remained there. Since the United States is a party to The Hague Abduction Convention, the father sought legal advice from the US Central Authority established under the Convention. The Central Authority advised him that since Malaysia was not a party to the Convention, he could do nothing to get his daughter back unless she was moved to a State party to the Convention.

\footnotetext{
${ }^{57}$ Section 1, Child Abduction Act, 12 July 1984, the United Kingdom.

${ }^{58}$ Section 4, Ibid.

${ }^{59}$ State Central Authority v Ayob, (1997) 21 Fam LR 567.
} 
After about two years, luck favoured the father when the mother contacted him, telling him that she wanted to travel to Australia. The father signed a visa application in respect of the daughter. Once the mother and daughter entered Australia, they were held at Melbourne airport. The Australian Central Authority then initiated proceedings for the return of the child to the United States. The Australian Court decided that removal of the child by her mother was wrongful under the Convention and ordered for the return of the child to US.

The lesson from this case is that if a child is abducted into Malaysia, the left-behind parent in the foreign country would be in a very difficult situation as he cannot rely on the automatic return mechanism under The Hague Abduction Convention due to the fact that Malaysia is not a party to the Convention. In that case, he has no other choice but to initiate expensive litigation in Malaysia, a foreign country, and the first tussle he has to encounter is the jurisdictional issue.

\section{The issue of jurisdiction}

Since this is a case that involves a foreign element, the preliminary question that arises is whether the Malaysian court has 'jurisdiction' to hear the case. By virtue of Section 23(1) of the Courts of Judicature Act 1964, "the High Court has jurisdiction to try all civil proceedings where the cause of action arose or the defendant resides within the local jurisdiction of the High Court." ${ }^{60}$ Unlike other common law countries, ${ }^{61}$ according to the Malaysian law, the 'presence' of the defendant is not adequate; he must be ordinarily 'resident' in Malaysia. Furthermore, section 24 (d) of the Act provides as follows:

"Without prejudice to the generality of section 23 the civil jurisdiction of the High Court shall include -a) jurisdiction under any written law relating to divorce and matrimonial causes; $\ldots$ d) jurisdiction to appoint and control guardians of infants and generally over the person and property of infants."

${ }^{60}$ Courts of Judicature Act 1964, Act 91, Section 23(1)(a) \& (b).

${ }^{61}$ According to the British practice, mere presence attracts jurisdiction of the English courts. See Maharanee of Baroda $v$ Wildenstein [1972] 2 QB 283 CA. 
As Malaysia practices a dual legal system, if the parties are Muslims, they are under the purview of Shari'ah courts. The jurisdiction of the Shari' ah courts is territorial in nature and can be exercised only within its territorial limit. ${ }^{62}$ In relation to the jurisdiction ratione personae, a Shari'ah court can hear and determine all civil actions and proceedings in which "all the parties are Muslims." ${ }^{, 63}$ The important corollary of this rule is that if one of the parties is not a Muslim, the Shari'ah court shall not exercise jurisdiction. ${ }^{64}$ Then which court shall exercise jurisdiction? The only logical interpretation of Article 121(1)A of the Federal Constitution, which provides that the civil "High Court shall have no jurisdiction in respect of any matter within the jurisdiction of the Shari'ah courts," is that the civil High Court has all the residual jurisdictional powers which are not entrusted to the Shari'ah courts. Therefore, if one of the parties is a non-Muslim and Shari'ah court has no jurisdiction, there is none other than the civil High Court that shall exercise jurisdiction. ${ }^{65}$

\section{The issue of recognition and enforcement of foreign judgments}

It is also possible that the left-behind parent might have obtained a lawful custodial order made by a court in his or her country and wanted to enforce the foreign custodial order against the abductor parent before the Malaysian court. This creates the issue of recognition and enforcement of foreign judgments.

${ }^{62}$ See, for example section 61(1) of the Administration of the Religion of Islam (State of Selangor) Enactment 2003, Enactment No 1 of 2003, 24 July 2003, which provides that "A Syariah High Court shall have jurisdiction throughout the State of Selangor."

${ }^{63}$ Section 61(3)(b), ibid.

64 "No decision of the Syariah ...Court shall involve the right or the property of a non-Muslim"; see section 74(1), ibid.

${ }^{65}$ See Indira Gandhi a/p Mutho v Pengarah Jabatan Agama Islam Perak \& Ors and other appeals [2018] 1 MLJ 545 (Federal court Full Panel decision of five judges). 
Under the Reciprocal Enforcement of Judgments Act (REJA) 1958, monetary judgments in personam from any of the reciprocating countries $^{66}$ can be registered and enforced in Malaysia. The requirements are that, "it must be a judgment of a superior court, which is final and conclusive and under which a sum of money is payable." ${ }^{67}$ "Once registered, the foreign judgments may be enforced like any Malaysian judgment. ${ }^{\$ 68}$ However, since REJA is concerned only with monetary judgments, foreign custody orders, which are non-monetary in nature, are not covered by it. ${ }^{69}$ There is no specific legislation for enforcement of foreign custody orders in Malaysia.

Let us look at the common law position on this matter. The common law principles on recognition and enforcement of foreign judgments are not very much different from the REJA. Apart from the requirement that it must be a judgment of a superior court, other requirements that "the judgment must be final and conclusive and that a sum of money must be payable" need also to be fulfilled. As far as the procedure is concerned, "a judgment creditor who wishes to enforce a monetary foreign judgment

${ }^{66}$ There are seven reciprocating countries: the United Kingdom, Hong Kong, Singapore, New Zealand, Sri Lanka, India, and Brunei Darussalam. See Reciprocal Enforcement of Judgments Act 1958, (Revised 1972) (Act 99), First Schedule.

${ }^{67}$ Ibid., section 3(3).

${ }^{68} \mathrm{Ibid}$., section 4(2).

${ }^{69}$ Furthermore, section 2 of REJA enunciates that "action in personam shall not be deemed to include any matrimonial cause or any proceedings in connection with any matrimonial matters, ...or guardianship of infants." 
at common law will have to commence a fresh action," be said as being more cumbersome than under the REJA. ${ }^{71}$

In Malaysia, there are reported cases of the enforcement of monetary foreign judgments only and until now there has not yet been any reported case on enforcement of non-monetary foreign judgments. This is understandable as the traditional common law approach does not allow the enforcement of non-monetary foreign judgments. ${ }^{72}$ It is therefore not possible for a foreign left-behind parent to enforce his or her foreign custodial order in Malaysia. He or she has to initiate a fresh action on custody before the Malaysian court and the court will of course apply the Malaysian law on custody.

\section{The best interests of the child: the paramount consideration}

The fundamental common law rule ${ }^{73}$ is that custody orders are not final and conclusive ${ }^{74}$ as the circumstances of parents and children very often change and thus custody orders are always subject to revision. This is indeed in furtherance of the basic precept of the family law commonly accepted in most jurisdictions, namely: The best interest of the child is always the paramount consideration.

${ }^{70}$ See, for example, CBM Construction Sdn Bhd v Builtcon and Development Sdn Bhd [1999] MLJU 71 at 7; Swee Hua Daily News Bhd v Tan Thein Chin [1996] 2 MLJ 107; and Charles Priya Marie v Koshy Cherian [2010] 6 CLJ 693 at 38.

${ }^{71}$ Adeline Chong, Recognition and Enforcement of Foreign Judgments in Asia (Asian Business Law Institute, Singapore, 2017) 131. Accessed 17 November, 2018: http://ink.library.smu.edu.sg/sol_research/2496.

${ }^{72}$ Ibid.

${ }^{73}$ By virtue of section 27 of the Civil Law Act 1956 (Act 67), Malaysian courts as a rule apply "English common law rules relating to custody and control of infants having regard to the religion and customs of the parties concerned."

${ }^{74}$ McKee v McKee (1951) AC 352. 
In Mahabir Prasad v. Mahabir Prasad, ${ }^{75}$ the father was a Malaysian citizen, married to an Indian citizen. They were married in Bombay in 1972 and the infants were born there. The father left India in 1974 but the mother and the infants remained and lived in India, until 1978, when they came to Malaysia. In January 1980 the marriage broke down. According to the deed of separation, custody of the infants was given to the father. The mother returned to India and subsequently filed a divorce petition for the dissolution of the marriage and also applied for the custody of the infants. The father was represented at the hearing. The Bombay court made an interim order granting custody of the infants to the mother pending the trial of the divorce petition. The father undertook to produce the infants on the date fixed for hearing but he failed to do so, and the Bombay Court granted an order of dissolution of the marriage on the ground of cruelty and awarded custody of the infants to the mother.

The father took the two infants back to Malaysia and then applied for custody of the children in the High Court, Kuala Lumpur but his application was dismissed as the learned Judge was of the view that the father was estopped from making the application in view of the decision of the Bombay Court.

The father then appealed to the Federal Court, which reversed the High Court's decision and decided that, "in the questions of custody the welfare and the best interests of the children must be the first and paramount consideration." The Court further held that "a custody order cannot from its nature be final or irreversible. It is only of persuasive authority." The court held that "a change of circumstances could justify a reassessment of the matter." The case was arranged for a rehearing at the High Court before another judge, who decided in favour of the mother on the basis that it was in the best interest and welfare of the children to live with their mother in India.

\section{The doctrine of forum non conveniens}

Alternatively, if the abductor parent has initiated custodial proceedings in Malaysia, the left-behind parent would like to challenge the proceedings before the Malaysian court, relying on custodial order he or she had

${ }^{75}$ Mahabir Prasad v. Mahabir Prasad [1982] 1 MLJ 189. 
obtained in the foreign country. The foreign parent may rely on the concept of forum non conveniens, arguing that the Malaysian court is not the appropriate forum to decide the case as the case is more closely connected with the foreign court.

The House of Lords per Lord Goff in The Spiliada ruled that the court will grant a stay of proceeding:

“...where the court is satisfied that there is some other available forum, having competent jurisdiction, which is the appropriate forum for the trial of the action, i.e. in which the case may be tried more suitably for the interests of all the parties and the ends of justice., ${ }^{76}$

An in-coming cross-border parental abduction case, where the doctrine of forum non conveniens was applied, is Herbert Thomas Small $v$ Elizabeth Mary Small. ${ }^{77}$ In this case, the husband, wife and child were all Australian citizens. The husband removed the child from Australia and entered Malaysia without the wife's knowledge. The husband obtained interim custody orders from the Malaysian civil court. In the meantime, the wife had obtained custody and return orders from the Australian courts and applied to set aside the husband's Malaysian court orders. The Malaysian court ordered the return of the abducted child on the grounds, among others, of forum non conveniens and the welfare of the child.

The court argued that the Australian court was the more appropriate forum to hear the dispute as to child custody as Australia had the most real and substantial connection with the action. This was because: (a) the daughter had no right of permanent residence in Malaysia; (b) the parties are all Australians and had been residing in Australia prior to the daughter's abduction; (c) the daughter was well-settled in Australia, was attending school in Australia, and hence had close cultural connections with Australia; (d) the plaintiff husband himself only had a tenuous connection with Malaysia through the 'Malaysia My Second Home Programme'; and (e) issues concerning the relationship of the daughter

76 Spiliada Maritime v Consulex Ltd [1987] AC 460 (HL). See also RH Hickling and Wu Min Aun, "Stay of Proceedings and Forum Non Conveniens," [1994\} $3 M L J$ xcvii.

${ }^{77}$ Herbert Thomas Small v Elizabeth Mary Small (2006) 6 MLJ 372. 
with her parents occurred during their time in Australia and are best inquired into by the Australian court. ${ }^{78}$

\section{Out-going Cases}

An out-going case which has received public attention is the case of Raja Bahrin, a Terengganu prince. ${ }^{79}$ He married an Australian woman in 1981 under Islamic law and they had two children. The family lived in Malaysia and upon the breakdown of the marriage, the mother took the children to Melbourne on the pretext of visiting their sick greatgrandmother and there she filed an application for the custody and guardianship of children. The husband then contested the application and the Australian Court ordered the parties and children to return to Malaysia and have the issue determined by the Malaysian Court. Raja Bahrin was granted orders for custody of the children from the Malaysian Shari'ah Court. The decision of the Australian Court however, was reversed on appeal by the Australian Full Family Court, whereby the wife was granted sole custody.

In 1992, the father discovered that the wife, now remarried, had, without his knowledge and consent, baptised the children and changed their Muslim names to her surname. Unhappy with this development, Raja Bahrin went to Australia, abducted the children and brought them back to Malaysia without the mother's knowledge. The father and children were Muslims; thus, under Islamic law, when the mother remarried, she would have been disqualified from having custody of the children once she left Islam. The mother did not return to Malaysia, and being non-Muslim, the Shari'ah courts were not conferred jurisdiction over her; neither could she file an application in the civil courts because the father and children were Muslims and they would be governed by the Shari'ah courts. This remains an unresolved legal conundrum.

It is worthy to take note that this case happened at the time where Australia was a non-Hague country. The situation would be different if

\footnotetext{
${ }^{78}$ Chan Wing Cheong, "A Judicial Response to Parental Child Abduction," [2008] 2 MLJ i.

${ }^{79}$ In the marriage of Y\&K Raja Bahrin (1986) 11 The Family Law Report 233.
} 
both Malaysia and Australia were Contracting states to The Hague Abduction Convention as the Australian Court would certainly apply the return remedy under the Convention and order for an automatic return of the children to their country of habitual residence i.e. Malaysia. This would lessen the length of the litigation and any possible harm to the children, particularly in this case where the children were abducted by the father from Australia to Malaysia by way of land and sea.

The case of Nicholas Tan Chye Seng $v$ Au Gek Wee $e^{80}$ is also a very pertinent case, which clearly illustrates the point that a Malaysian child abducted to a foreign country could not be protected and the Malaysian father could not get back the child as Malaysia is a non-Convention country. In this case, the plaintiff husband, the defendant wife and their son were all Malaysians at all material times, living in Malaysia. Their son was attending the Alice Smith School in Kuala Lumpur. On $19^{\text {th }}$ June 2013 the parents were alleged to have had an argument. One week after that the wife took their son to Singapore without the knowledge of the husband. On $17^{\text {th }}$ July 2013 , the plaintiff husband filed an application in the Kuala Lumpur High Court for the sole custody, care and control of the son, with reasonable right of access given to the wife. The wife applied for the stay of proceedings as the Malaysian High Court had no jurisdiction and also on the ground of forum non-convenience and/or lis alibi pendens, as she had initiated an action against the plaintiff husband in the Singaporean High Court on $31^{\text {st }}$ July $2013 .^{81}$

The Malaysian Court ruled that it had jurisdiction and it was forum convenience as all the parties and even the son who was abducted were Malaysians, their domicile as well as habitual residence was Malaysia, and the cause of action occurred in Malaysia. The Court also ruled that the husband was granted interim sole custody of the child, and that the defendant shall forthwith return the said child to the jurisdiction of Malaysia and into the custody of the plaintiff.

Nevertheless, as Malaysia is a not a contracting State to The Hague Abduction Convention, the Malaysian father did not have the benefit of

\footnotetext{
${ }^{80}$ Nicholas Tan Chye Seng v Au Gek Wee (2013) 1 LNS 600.

${ }^{81}$ Nicholas Tan Chye Seng v Au Gek Wee, High Court (Kuala Lumpur) Case No. 24-149-07-2013.
} 
the summary return of his child under Hague Convention processes. ${ }^{82}$ This case is a lesson for all Malaysian parents, demonstrating clearly the disadvantage of being a non-Hague country.

\section{FINDINGS AND RECOMMENDATIONS}

When a cross-border child abduction occurs and the child is taken to a country that has not signed the 1980 Hague Abduction Convention, it is virtually impossible to return the child to the left-behind parent. Prior to the entry into force of The Hague Abduction Convention there were very limited chances of recovering an abducted child. Seeking legal redress in a foreign country by the left- behind parent is also a very difficult, costly and time-consuming process and could not expect any favourable results. This is the rationale behind the adoption by The Hague Conference on Private International Law of the three Hague Children's Conventions, namely: (1) the 1980 Child Abduction, the 1996 Child Protection, and the 2007 Child Support Conventions and all these three conventions are all complementary to the Convention on the Rights of the Child 1989.

It has been stated earlier that cross-border parental child abduction is a serious problem affecting Malaysian parents. We have also found that although Malaysia has adequate substantive laws and procedural laws to deal with child custody cases, there is no proper system of local law on recognition and enforcement of foreign custodial orders and it is disadvantageous for both foreign parents and Malaysian parents in case of cross-border abduction cases. The only way to resolve this issue is to become part of an international legal regime by means of acceding to a relevant international convention. Besides, Malaysia is a party to the Convention on the Rights of the Child 1989 and thus bound by its provisions. One of the obligations related to cross-border child abduction, which is laid down in Article 11 of the Convention, is "to combat illicit

${ }^{82}$ See Goh Siu Lin, "The Fraught Area of International Child Abduction: The Malaysian Perspective," Family Law Update, (The International Bar Association Legal Practice Division, December 2016),

12. 
transfer and non-return of children abroad, in particular by entering into international agreements to this end." ${ }^{, 3}$

All these leads to only one direction, for Malaysia to accede to the 1980 Child Abduction Convention. However, another crucial question remains, i.e is Malaysia ready for that? The answer appears to be in the negative. Like many other Muslim countries, Malaysia also has concerns on how the Convention will have effect on Malaysia's domestic laws, in particular Islamic law enactments, as Islamic law is under the jurisdiction of various states, and whether it will work properly within the dual legal system of Malaysia. Expert's Roundtable Discussions on The Hague Children Conventions were held on 25-26 October 2017 in the Senate Hall of the International Islamic University Malaysia, inviting the Secretary General of The Hague Conference on Private International Law $(\mathrm{HCCH})$, experts from the Attorney General's Chambers of Malaysia, judges from the civil and Shari'ah courts, experts from various states Islamic law Departments, and academia. While admitting that they need to have more in-depth understanding of the practical functioning of Hague Children Conventions, the overwhelming majority of the participants voiced their clear view that Malaysia should not accede to the Conventions. ${ }^{84}$

The following are the recommendations:

(1) In order to properly and effectively address the issue of international parental child abduction in the long run it is necessary to accede to the 1980 Hague Abduction Convention. However, the situation on the ground in Malaysia is very clearly against it. The concerns are legitimate and understandable.

(2) To attract more Muslim countries, including Malaysia, it is recommended that $\mathrm{HCCH}$ needs to:

${ }^{83}$ Article 11, Convention on the Rights of the Child, adopted by the UN General Assembly on 20 November 1989.

${ }^{84}$ Expert's Roundtable Discussions on the Hague Children Conventions, 25-26 October 2017, Senate Hall, International Islamic University Malaysia, Kuala Lumpur, Malaysia. 
"hold more symposia and workshops in these countries about the Convention. The $\mathrm{HCCH}$ must also translate the Convention and its key provisions and concepts into the national languages of Muslim countries so that there will be better understanding of its principles. Most importantly, it is required to resolve the popular misunderstandings in Muslim countries that the convention is an attempt to harmonise substantive local laws, including Shari'ah laws, of member countries and to clear the air that to the contrary, it merely standardises private international law by choosing the law of the country of habitual residence of the child as the governing law for custodial disputes." 85

(3) If the government of Malaysia wants to consider accession to the Convention in the future, it may need to have consultations and roundtable discussions with stakeholders from various states as Islamic law is under the purview of the states under the Federal Constitution. The final arbiter in the decision-making would be the Conference of Rulers.

(4) In the meantime, necessary law reforms are recommended to curb the issue of international parental child abduction. It is true that we have adequate legal provisions for the prevention of parental child abduction in the IFLA as well as LRA. However, the most that can be done against the wrong-doer is contempt of court. On the other hand, the Penal Code cannot be relied upon to combat parental child abduction in Malaysia. The partial criminalising effect of parental child abduction can be found only in the Child Act. The better option would, therefore, be to revise and strengthen Section 52 of the Child Act 2001 by making it an offence even for a custodial parent to take a child outside of Malaysia without the consent and against the visitation and guardianship rights of the other parent.

\section{CONCLUSION}

As discussed earlier, in Malaysia, laws on child custody and child abduction are substantially adequate. Although there are a few

${ }^{85}$ See Abdul Ghafur Hamid, et al, "The Applicability of the 1980 Hague Abduction Convention in Muslim Countries...", 28-29. 
outstanding issues of conflict of jurisdiction between civil and Shari'ah courts, in particular in cases involving conversion, many could be put to rest by the recent decisions of the Apex Court ${ }^{86}$ and the much awaited proposed amendments to the Law Reform (Marriage and Divorce) Act $1976 .^{87}$ The Child Act 2001 is also an advantage for Malaysia in the protection of Malaysian children although it is necessary to improve its implementation.

Parental child abduction is a worldwide and growing phenomenon affecting both Muslim and non-Muslim countries. There are, however, concerns on the part of Muslim countries that The Hague Abduction Convention would affect the Islamic principles on child custody and the powers of the Shari'ah courts. A careful perusal of the Convention, however, would make one fairly convinced that the convention in no way unifies domestic child custody laws of the contracting states and thus not affecting the substantive law principles under the Islamic law. The key objective of the convention is to merely unify private international law of contracting states by choosing 'habitual residence' as the applicable personal connecting factor and to promptly return the abducted child to the country of his habitual residence. Nevertheless, it would remain a long journey for most Muslim countries, including Malaysia, to join the international legal regime. It would rather be in the best interest of Malaysia, as a country for the time being to strengthen its domestic laws to address the issue of cross-border parental child abduction.

\footnotetext{
${ }^{86}$ Indira Gandhi a/p Mutho v Pengarah Jabatan Agama Islam Perak \& Ors and other appeals [2018] 1 MLJ 545 (Federal court Full Panel decision of five judges).

87 "Law Reform (Marriage and Divorce) Act 1976 Amendment Bill Tabled in Parliament," New Straits Times, 21 November 2016. However, on 6 April 2017, it was announced by Dato' Sri Dr. Zahid Hamidi, the former Deputy Prime Minister, that the tabling of the Amendment Bill was postponed; see "Amendments to Marriage and Divorce Act Postpones", The Star Online, 6 April 2017.
} 
